\title{
Seasonal changes in the sinking export of particulate material under first-year sea ice on the Mackenzie Shelf (western Canadian Arctic)
}

\author{
Thomas Juul-Pedersen ${ }^{1,2,4, *}$, Christine Michel ${ }^{1}$, Michel Gosselin ${ }^{2}$, Lena Seuthe ${ }^{3}$ \\ ${ }^{1}$ Freshwater Institute, Fisheries and Oceans Canada, 501 University Crescent, Winnipeg, Manitoba R3T 2N6, Canada \\ ${ }^{2}$ Institut des sciences de la mer (ISMER), Université du Québec à Rimouski, 310 Allée des Ursulines, Rimouski, \\ Québec G5L 3A1, Canada \\ ${ }^{3}$ Norwegian College of Fisheries Science, University of Tromsø, 9037 Tromsø, Norway \\ ${ }^{4}$ Present address: Greenland Institute of Natural Resources, PO Box 570, 3900 Nuuk, Greenland
}

\begin{abstract}
The sinking export of particulate material under landfast first-year sea ice was studied from the winter period to spring melt on the Mackenzie Shelf, western Canadian Arctic. Short-term particle interceptor traps were deployed at 1, 15, and $25 \mathrm{~m}$ under the ice on 16 consecutive occasions from 23 February to 20 June 2004. The sinking material was analyzed for chlorophyll (chl) $a_{\text {, phaeo- }}$ pigments, total particulate carbon (TPC), particulate organic carbon and nitrogen (POC and PON), and biogenic silica (BioSi). The sinking fluxes of chl $a$ and BioSi increased steadily after 19 March and until the onset of spring melt (26 May), after which they increased considerably. The contribution of large algae $(>5 \mu \mathrm{m})$ to the total chl a sinking flux also increased after 19 March, reflecting an increasing contribution of diatoms to the sinking export of algal material. Accordingly, chl a sinking fluxes at $1 \mathrm{~m}$ showed a significant linear relationship with bottom ice chl a biomass. On average, $46 \%$ of the $\mathrm{chl}$ a exported at $1 \mathrm{~m}$ was lost in the upper $25 \mathrm{~m}$. POC was the main component of the TPC sinking fluxes throughout the study. POC sinking fluxes remained fairly stable until the onset of spring melt, after which a considerable increase was observed. High POC:chl a ratios indicated a significant contribution of non-algal material to the sinking POC. The daily sinking loss rate of chl $a_{1}$ POC, and PON from the sea ice and interfacial layer (top $1 \mathrm{~m}$ of the water column) varied seasonally and was highest during the winter period. Our results illustrate the continuous downward sinking export of organic material under landfast ice, from winter throughout late spring.
\end{abstract}

KEY WORDS: Arctic $\cdot$ Sea ice $\cdot$ Sedimentation $\cdot$ Sea ice-water coupling $\cdot$ Organic material $\cdot$ Carbon flux $\cdot$ Ice algae $\cdot$ Biogenic silica

- Resale or republication not permitted without written consent of the publisher

\section{INTRODUCTION}

The sinking export of organic material at the termination of phytoplankton blooms is a key process by which primary-produced material from surface waters is transferred to the benthos (e.g. Turner 2002). In ice-covered seas, where sea ice primary production precedes the phytoplankton bloom, the sinking of organic material from the sea ice may provide an early source of material for benthic communities (e.g. McMahon et al. 2006). In the Arctic Ocean, most sea ice primary production takes place in first-year sea ice, which is primarily found on shelf areas. Arctic continental shelves make up more than half ( $53 \%$; Jakobsson 2002) of the total area of the Arctic Ocean and adjacent seas. On these shallow shelves, higher annual primary production (phytoplankton and ice algal production) is found compared to the central Arctic Ocean (e.g. Gosselin et al. 1997). Ice algal chlorophyll (chl) a biomass in the bottom layer of Arctic first-year sea ice may vary considerably between areas and may reach concentrations of $250 \mathrm{mg} \mathrm{m}^{-2}$ (Smith et al. 1990). Although light and nutrient conditions can limit ice algal production (e.g. Gosselin et al. 1990), the production period of ice algae typically extends until 
they are released from the sea ice at the time of spring ice melt (e.g. Michel et al. 1996).

Ice algal communities in the Arctic are directly grazed upon by pelagic copepods and amphipods (e.g. Werner 2000, Fortier et al. 2002) and, to a lesser extent, by sympagic fauna (Nozais et al. 2001, Michel et al. 2002). The bulk of the ice algal biomass is mainly released into the water column at the time of spring ice melt (Tremblay et al. 1989, Michel et al. 1996, 2002, Fortier et al. 2002). However, Melnikov (1998) suggested an export of material from the sea ice during ice growth, as a result of episodic brine drainage. Based on this study, Lavoie et al. (2005) applied a continuous export of ice algae from the sea ice throughout the period of ice algal development in a model of ice algal growth and decline in Arctic first-year sea ice.

Primary-produced particulate organic material (POM) may either sink directly as intact algal cells or be diverted to the pelagic heterotrophic food web (e.g. Wassmann 1998, Turner 2002), which affects the composition of the sinking material. The sinking of intact algal cells may result in better preservation of the sinking POM (e.g. Turner 2002), although some loss usually occurs during sinking (e.g. release of dissolved material and dissolution). Algal cells released from the sea ice may either sink as intact cells or form aggregates, which may increase their sinking velocities and therefore decrease their residence time in the pelagic zone (e.g. Wassmann 1998). The other export pathway, through the heterotrophic food web, affects both the quantity and composition of the sinking particulate organic material (e.g. Turner 2002), and a considerably reduced amount of the ingested carbon may be reintroduced to the water column as fecal material (e.g. Møller et al. 2003). The efficiency of the heterotrophic food web in utilizing the sinking material is thought to depend largely on the timing and rate of release of the material from the sea ice in relation to the seasonal presence of grazers (e.g. Michel et al. 1996, Fortier et al. 2002). In northern Baffin Bay, ca. $75 \%$ of the bottom first-year sea ice carbon biomass was observed sinking as intact algal cells (at $1 \mathrm{~m}$ under the sea ice; Michel et al. 2002), while ca. $60 \%$ of the ice algal production was estimated to be channeled through pelagic herbivores in Resolute Passage, Canada (Michel et al. 1996). Sinking ice algae are believed to provide a seasonally important food source for pelagic (e.g. Michel et al. 1996, Werner 2000, Fortier et al. 2002) and benthic (e.g. McMahon et al. 2006) communities.

The Mackenzie Shelf in the western Canadian Arctic covers an area of ca. $60 \times 10^{3} \mathrm{~km}^{2}$ (defined by the $200 \mathrm{~m}$ isobath) and generally experiences a landfast inshore first-year sea ice cover from December to May-June and drifting pack ice on the outer shelf during winter (Carmack \& Macdonald 2002). Primary production on the Mackenzie Shelf has been estimated at 12 to $16 \mathrm{~g} \mathrm{C} \mathrm{m}^{-2} \mathrm{yr}^{-1}$ (Carmack et al. 2004), and ice algae are estimated to account for $<15 \%$ of the annual primary production (Horner \& Schrader 1982, Macdonald et al. 1998). Ice algae have been observed forming dense mats on the undersurface of the sea ice on the Mackenzie Shelf, which were later dislodged from the sea ice during spring melt and sea ice break-up (Macdonald et al. 1998). These events could result in a large proportion of organic material reaching the benthos unutilized, if exceeding the grazing capacity of the pelagic heterotrophic food web. Indeed, Seuthe et al. (2007) showed that the under-ice copepod community in Franklin Bay on the Mackenzie Shelf increased their grazing activity from March to May 2004. Studies of sinking fluxes under the sea ice on the Mackenzie Shelf are from long-term sediment trap moorings (O'Brien et al. 2006, Forest et al. 2007). From these studies, the annual particulate organic carbon (POC) sinking flux was estimated to vary between 1.7 and $5.8 \mathrm{~g} \mathrm{C} \mathrm{m}^{-2} \mathrm{yr}^{-1}$ (deployment depths ranging from 118 to $213 \mathrm{~m}$; $\mathrm{O}^{\prime}$ Brien et al. 2006) and 1.0 to

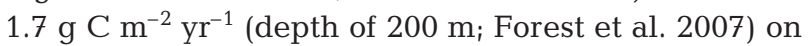
the Mackenzie Shelf.

The present study investigated the seasonal changes in the sinking flux of particulate material under firstyear sea ice on the Mackenzie Shelf during late winter and spring 2004. Our first objective was to estimate under-ice sinking fluxes of particulate material during the period of ice growth and prior to ice algal production, in contrast to the later productive season and the period of ice melt. The duration of this study ensured that the entire productive season of ice algae was covered and that a complete seasonal time-series of under-ice sedimentation, from late winter to spring melt, was obtained. Our second objective was to evaluate depth-related changes in under-ice sinking fluxes of organic material and in the composition of the sinking material, after its release from the ice into the water column. Our third objective was to quantify sinking export processes with respect to the standing chl $a$, POC, and particulate organic nitrogen (PON) biomass in the bottom sea ice and the upper part of the water column.

\section{MATERIALS AND METHODS}

Sampling. Under-ice sampling was conducted at a landfast first-year sea ice station (ca. $250 \mathrm{~m}$ water depth) in Franklin Bay, western Canadian Arctic (Fig. 1). This study was carried out onboard the Canadian research ice-breaker 'CCGS Amundsen' during the overwintering period of the Canadian Arctic Shelf Exchange Study (CASES). From 23 February to 20 June 2004, sinking fluxes of particulate material from the sea ice were stud- 


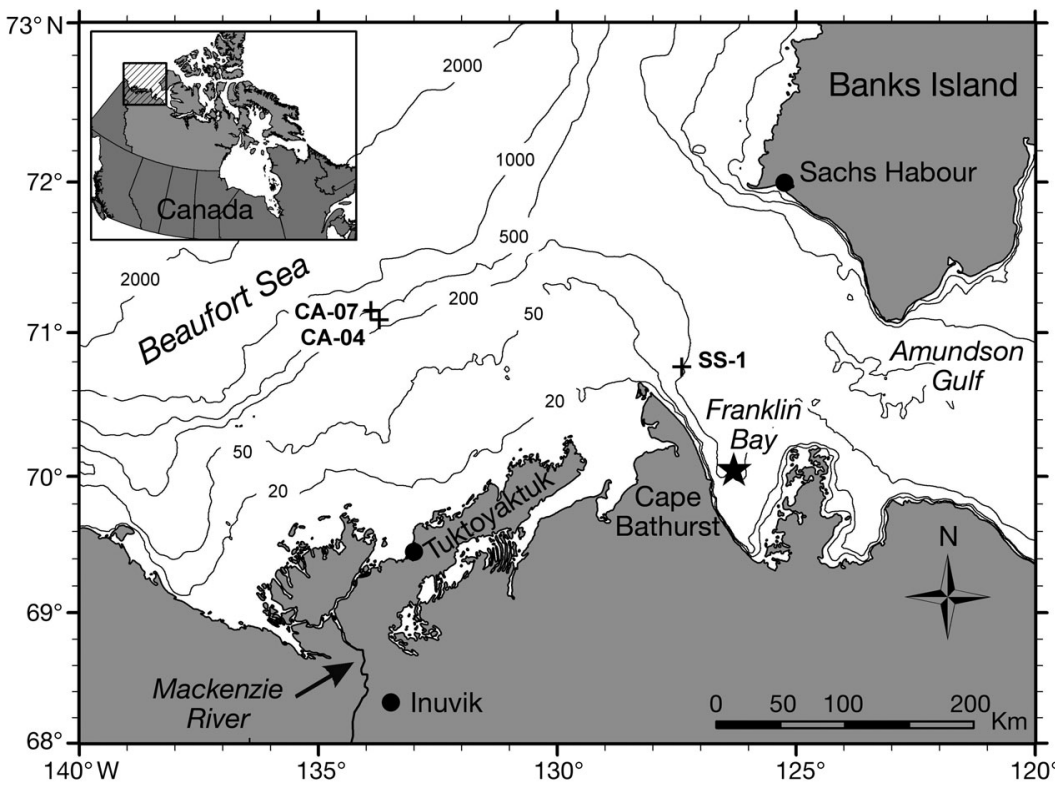

Fig. 1. Sampling station (indicated by star) in Franklin Bay on the Mackenzie Shelf, western Canadian Arctic. For comparison, the positions of sediment trap moorings CA-04 and CA-07 of Forest et al. (2007) and Stn SS-1 of O'Brien et al. (2006) are shown. Water depth in $\mathrm{m}$

ied using particle interceptor traps deployed at 1, 15, and $25 \mathrm{~m}$ from the undersurface of the ice. Two identical particle interceptor trap arrays, fixed to a tripod on the sea ice, where deployed in relatively close proximity (ca. $50 \mathrm{~m}$ ) on 16 consecutive occasions (Table 1). The ice holes through which the sediment traps were deployed were covered by wooden plates and snow to prevent increased light penetration. During the initial part of the study, from 23 February to 13 April, the deployment time was $7.8 \pm 0.8 \mathrm{~d}$ (mean $\pm \mathrm{SD}, \mathrm{n}=6$ ). From 13 April to 20 June, the deployment time was reduced to an average of $6.2 \pm 0.4 \mathrm{~d}(\mathrm{n}=8)$ in response to higher sinking fluxes, except for 2 deployments of 4.0 and $15.2 \mathrm{~d}$ on 26 May and 30 May, respectively. The particle interceptor traps were constructed of polyvinyl chloride (PVC) cylinders closed at one end, with an internal diameter of $10 \mathrm{~cm}$ and an aspect ratio (height:diameter) of 7. The sampling with particle interceptor traps was carried out in accordance with Joint Global Ocean Flux Study (JGOFS) protocols (Knap et al. 1996) and recommendations by Gardner (2000). Prior to deployment, the particle interceptor traps were filled with $0.22 \mu \mathrm{m}$ filtered seawater previously collected at $200 \mathrm{~m}$ to ensure that the higher density particle-free water would remain within the traps during deployment. No preservatives were added to the filtered seawater prior to deployment. Upon recovery, the entire sample volume of the particle interceptor traps was transported back to the laboratory onboard the 'CCGS Amundsen' for chl $a$, phaeopigments, total particulate carbon (TPC), $\mathrm{POC}, \mathrm{PON}$, and biogenic silica (BioSi) analyses.
Surface water samples were collected at $1 \mathrm{~m}$ using a 51 Niskin bottle. During a parallel study on sea ice microbial communities in the same area, the bottom $4 \mathrm{~cm}$ of ice cores were collected using a Mark II manual ice corer $(9 \mathrm{~cm}$ internal diameter, Kovacs Enterprises), as described in detail by Riedel et al. (2006). Ice core samples were collected at 2 sites representative of high and low snow cover, although results from the 2 sites were later averaged for the present study. The surface water and ice core samples were brought back to the laboratory onboard the ship for chl $a_{\text {, }}$ POC, PON, and salinity analyses.

Analyses. In the laboratory onboard the ship, the total volume of the traps was measured, pre-screened on a $425 \mu \mathrm{m}$ mesh to remove larger swimmers, and transferred into dark containers. The samples were gently mixed before subsampling for analyses.

Total chl $a$ and total phaeopigments were measured in duplicate on 100 to $500 \mathrm{ml}$ subsamples filtered through Whatman GF/F $25 \mathrm{~mm}$ filters. Starting on 27 March, size-fractionated chl $a$ and phaeopigments $(>5 \mu \mathrm{m})$ were measured on samples filtered through Nuclepore polycarbonate $5 \mu \mathrm{m}$ membranes. The filters and membranes were extracted in $10 \mathrm{ml}$ of $90 \%$ acetone during $24 \mathrm{~h}$ at $4^{\circ} \mathrm{C}$ in dark conditions and ana-

Table 1. Sampling periods, dates of deployment and recovery, and duration of the under-ice deployments of particle interceptor traps in Franklin Bay, western Canadian Arctic, in 2004

\begin{tabular}{|lllc|}
\hline \multirow{2}{*}{ Period } & \multicolumn{2}{c}{ Sampling date } & \multirow{2}{*}{$\begin{array}{c}\text { Duration } \\
\text { (d) }\end{array}$} \\
\cline { 2 - 3 } & Deployment & Recovery & \\
\hline \multirow{5}{*}{ Winter } & 23 February & 03 March & 8.7 \\
& 03 March & 11 March & 7.8 \\
& 11 March & 19 March & 7.9 \\
Early & 19 March & 27 March & 8.0 \\
spring & 27 March & 05 April & 8.9 \\
& 05 April & 13 April & 7.9 \\
& 13 April & 19 April & 6.0 \\
& 19 April & 25 April & 6.0 \\
& 25 April & 01 May & 6.0 \\
& 01 May & 07 May & 6.0 \\
& 07 May & 14 May & 7.0 \\
& 14 May & 20 May & 6.0 \\
Melt & 20 May & 26 May & 6.0 \\
& 26 May & 30 May & 4.0 \\
& 30 May & 14 June & 15.2 \\
& 14 June & 20 June & 6.3 \\
\hline
\end{tabular}


lyzed on a Turner Designs 10AU fluorometer, using $90 \%$ acetone as a blank. Chl $a$ and phaeopigment concentrations were estimated according to Parsons et al. (1984). The fluorometer was calibrated before and after the expedition, using a pure chl a extract (from Anacystis nidulans; Sigma).

TPC, POC, and PON were measured in duplicate on 100 to $1000 \mathrm{ml}$ subsamples that were filtered on precombusted $\left(450^{\circ} \mathrm{C}\right.$ during $\left.24 \mathrm{~h}\right)$ Whatman GF/F $21 \mathrm{~mm}$ filters. The filters were dried at $60^{\circ} \mathrm{C}$ during $24 \mathrm{~h}$, pelletized and stored until later analysis on a PerkinElmer Model 2400 CHN analyzer. POC was obtained by acidifying filters in a desiccator saturated with $\mathrm{HCl}$ fumes over a period of $24 \mathrm{~h}$ to remove any inorganic carbon before analysis on the CHN analyzer. POC was sampled from 5 April onwards. Analysis of non-acidified filters produced values of TPC and PON.

BioSi was measured in duplicate on 100 to $500 \mathrm{ml}$ subsamples. The subsamples were filtered on $0.6 \mu \mathrm{m}$ Nuclepore polycarbonate membranes using an allplastic filtration system and were dried at $60^{\circ} \mathrm{C}$ for $24 \mathrm{~h}$. BioSi was measured by extraction in $0.2 \mathrm{M} \mathrm{NaOH}$ at $95^{\circ} \mathrm{C}$ for $45 \mathrm{~min}$. Extracted subsamples were then analyzed using a colorimetric reaction involving the formation of a silicomolybdate complex, which was spectrophotometrically determined at $810 \mathrm{~nm}$ (Varian CARY $100 \mathrm{BIO}$; adapted from Ragueneau \& Tréguer 1994 and Conley 1998).

The same methods as described above were used to determine chl $a, \mathrm{POC}$, and PON concentrations from surface water samples and melted ice cores. Surface water salinity was determined using an Autosal Model 8400B salinometer. Before filtration, the bottom sea ice samples were processed as described by Riedel et al. (2006).

Calculations and statistical analyses. Sinking fluxes $\left(\mathrm{mg} \mathrm{m} \mathrm{m}^{-2} \mathrm{~d}^{-1}\right.$ ) were calculated using the following equation:

$$
\text { Sinking flux }=\left(C_{\text {trap }} \times V_{\text {trap }}\right) /\left(A_{\text {trap }} \times T_{\text {dep }}\right)
$$

where $C_{\text {trap }}$ is the concentration of the measured variable in the particle interceptor trap $\left(\mathrm{mg} \mathrm{m}^{-3}\right), V_{\text {trap }}$ is the volume of the particle interceptor trap sample $\left(\mathrm{m}^{3}\right)$, $A_{\text {trap }}$ is the particle interceptor trap surface area $\left(\mathrm{m}^{2}\right)$, and $T_{\text {dep }}$ is the deployment time (d).

The daily loss rate $\left(\% \mathrm{~d}^{-1}\right)$ of suspended material due to sinking export at $1 \mathrm{~m}$ was estimated using the following equation:

$$
\text { Daily loss rate }=\text { Sinking flux } \times 100 / C_{\text {int }}
$$

where sinking flux at $1 \mathrm{~m}$ is from Eq. (1) and $C_{\text {int }}$ is the integrated concentration of the variable considered $\left(\mathrm{mg} \mathrm{m}^{-2}\right)$ in the bottom sea ice and water column above the particle interceptor trap depth. Because of the missing chl a sinking flux at $1 \mathrm{~m}$ on 20 June, the chl a daily loss rate on that day was estimated using the chl $a$ sinking flux measured at $15 \mathrm{~m}$.

The seasonal time-series of sinking flux data was tested for significant differences between selected reference periods using Kruskal-Wallis tests (Sokal \& Rohlf 1981) and between depths using Friedman's method for randomized blocks (Sokal \& Rohlf 1981). Linear regression analyses between variables are simple linear regressions (Model I) and reduced major axis (Model II) regressions (Sokal \& Rohlf 1981); the latter takes into account measurement errors for both dependent and independent variables. Regression slopes were compared using analysis of covariance (Sokal \& Rohlf 1981).

\section{RESULTS}

The sampling period covered 3 distinctive time periods defined as winter, early spring, and melt period, as will be referred to in the next sections (Table 1). The winter period extended from 23 February to 19 March and was characterized by continuous sea ice growth from 1.4 to $1.6 \mathrm{~m}$ (Fig. 2a) and little changes in ice algal

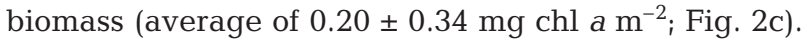
The early spring period, from 19 March to 26 May, showed continuing sea ice growth with ice thickness increasing from 1.6 to $2.0 \mathrm{~m}$ and an increase in ice

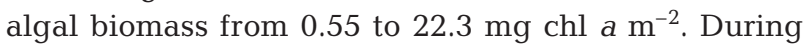
the melt period, from 26 May to 20 June, a decrease in sea ice thickness from 2.0 to $1.6 \mathrm{~m}$ and a decrease in surface salinity from 31.2 to 5.4 were observed (Fig. 2a, b), along with a decrease in the ice algal biomass from

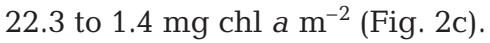

Sinking fluxes measured under the sea ice showed a general seasonal increase during the sampling period (Fig. 3a-d, Table 2). Chl a and BioSi sinking fluxes both showed a significant increase from winter to early spring and to the melt period (Kruskal-Wallis, $\mathrm{p}<0.05$; Fig. 3a,b, Table 2). During winter, chl $a$ and BioSi sinking fluxes remained low (median values of 0.01 and $\leq 0.80 \mathrm{mg} \mathrm{m}^{-2} \mathrm{~d}^{-1}$ at all depths, respectively), while a steady increase was observed during early spring, reaching 0.23 and $5.8 \mathrm{mg} \mathrm{m}^{-2} \mathrm{~d}^{-1}$ at $1 \mathrm{~m}$ on 26 May, respectively. During the following melt period, chl $a$ sinking fluxes increased 7 - to 9-fold, reaching 2.0 and $0.97 \mathrm{mg} \mathrm{m}^{-2} \mathrm{~d}^{-1}$ at 15 and $25 \mathrm{~m}$, respectively (unfortunately, data are not available for $1 \mathrm{~m}$ on 20 June). BioSi sinking fluxes increased 7 - to 13 -fold at all depths during the melt period, reaching 37.9, 90.4, and $72.0 \mathrm{mg} \mathrm{m}^{-2} \mathrm{~d}^{-1}$ at 1,15 , and $25 \mathrm{~m}$, respectively, on 20 June. Throughout the study, chl a sinking fluxes decreased significantly with depth, on average, 

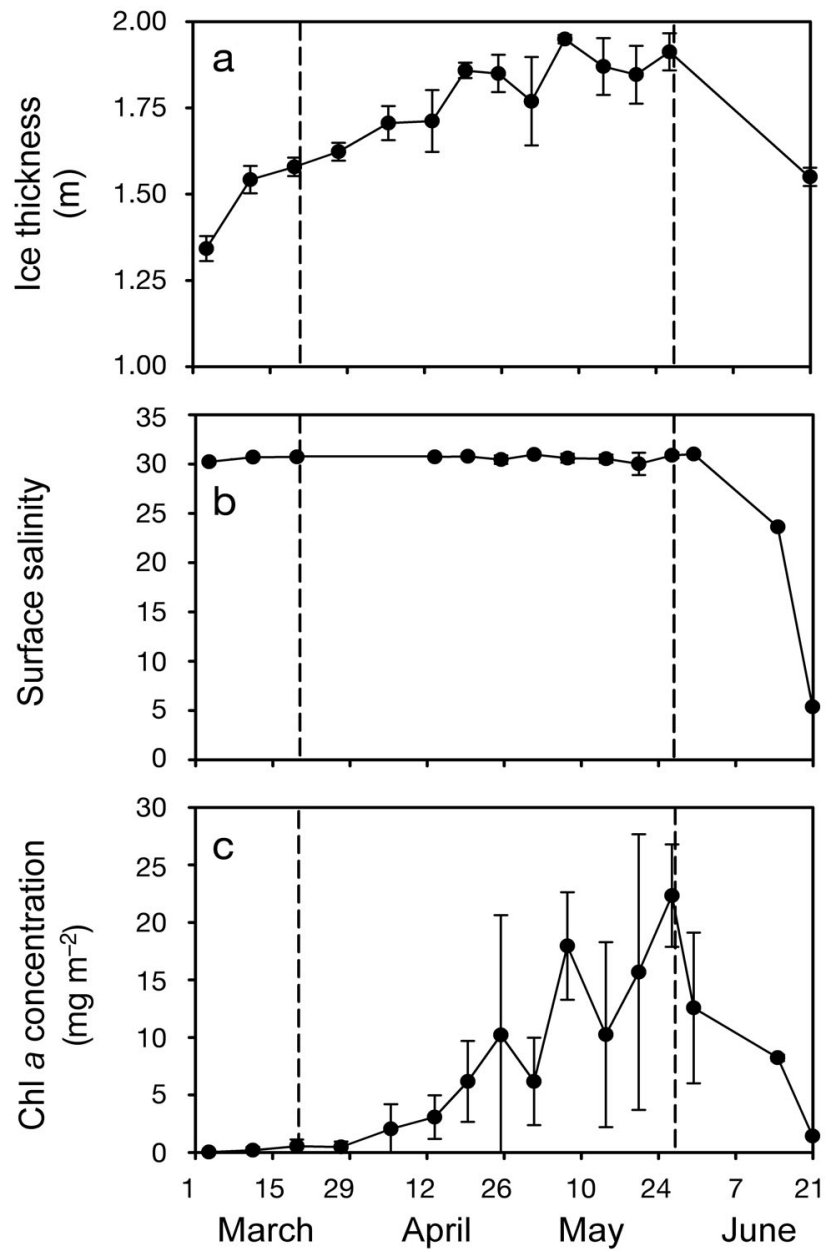

Fig. 2. Seasonal changes in (a) sea ice thickness, (b) surface salinity, and (c) sea ice chl a concentrations from 23 February to 20 June 2004. In (a) and (c), values were averaged from sites with high and low snow cover during deployment periods of particle interceptor traps. Error bars represent SD. Vertical dashed lines represent reference periods as described in Table 1

by $46.2 \pm 18.5 \%$ from 1 to 25 m (Friedman's method, $\mathrm{p}<0.001)$, while BioSi sinking fluxes remained stable with depth (Friedman's method, p > 0.05; Table 2). Sinking fluxes of phaeopigments increased significantly with depth throughout the study (Friedman's method, p < 0.05; Table 2).

TPC and POC showed parallel seasonal sinking flux patterns throughout the study (Fig. 3c,d, Table 2), which differed from chl $a$ and BioSi. Missing POC data points from 23 February to 27 March were extrapolated from the strong linear correlation between the measured sinking fluxes of TPC and POC (Fig.4), using the measured TPC sinking flux values. Sinking fluxes of TPC and POC remained rather stable during the winter (median values of 27.0 and $24.6 \mathrm{mg} \mathrm{m}^{-2} \mathrm{~d}^{-1}$ at $1 \mathrm{~m}$, respectively) and early spring (median values of 24.4
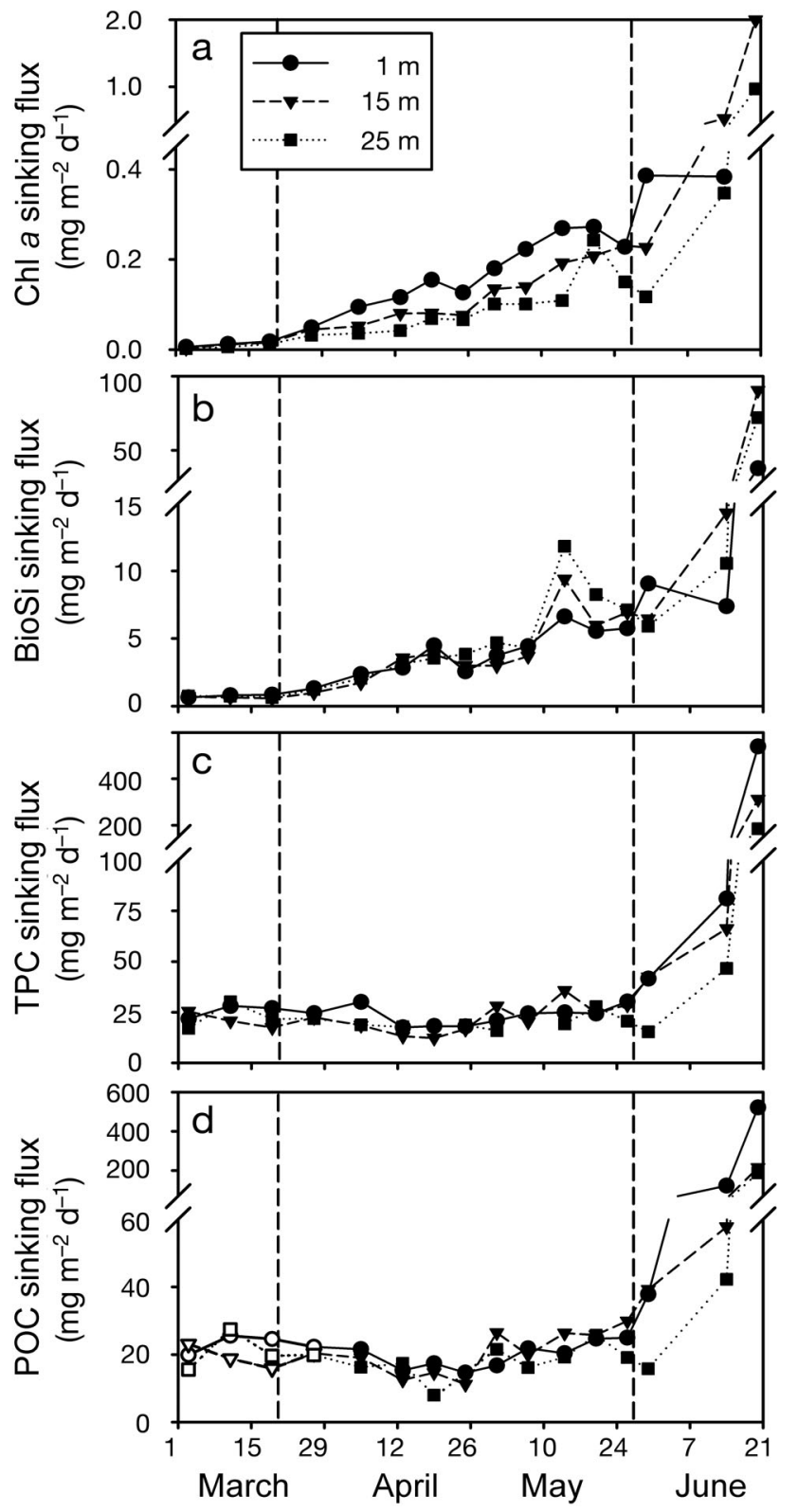

Fig. 3. Seasonal changes in sinking fluxes of (a) chl $a$, (b) biogenic silica (BioSi), (c) total particulate carbon (TPC) and (d) particulate organic carbon (POC) at 1, 15, and $25 \mathrm{~m}$ under the sea ice from 23 February to 20 June 2004. Data points represent particle interceptor trap recovery dates. The open data points in (d) are POC values estimated from the linear relationship between POC and TPC. Vertical dashed lines represent reference periods as described in Table 1

and $21.0 \mathrm{mg} \mathrm{m}^{-2} \mathrm{~d}^{-1}$ at $1 \mathrm{~m}$, respectively) periods. During the melt period, TPC sinking fluxes increased 9- to 18-fold (maximum values of 539.9, 312.8, and $185.5 \mathrm{mg} \mathrm{m}^{-2} \mathrm{~d}^{-1}$ at 1,15 , and $25 \mathrm{~m}$, respectively, on 20 June) and POC increased 7 - to 21 -fold (maximum values of $521.7,214.5$, and $188.6 \mathrm{mg} \mathrm{m}^{-2} \mathrm{~d}^{-1}$ at 1,15 , and $25 \mathrm{~m}$, respectively, on 20 June). TPC and POC sink- 


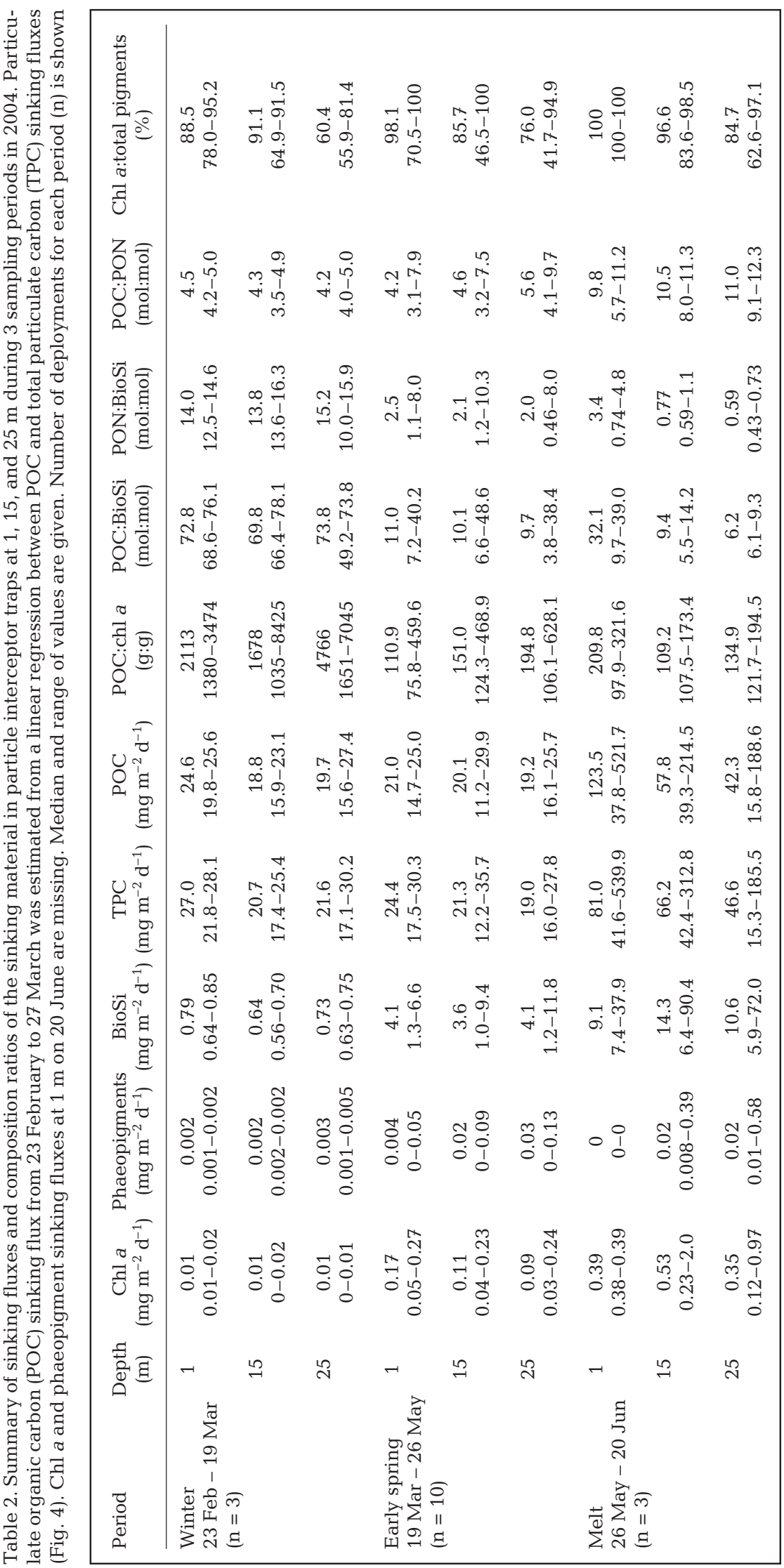

ing fluxes did not show any significant change with depth during the study period (Friedman's method, $\mathrm{p}>0.05$; Table 2). Throughout our study, POC was the main component of the TPC sinking fluxes making up ca. $91 \%$ of the sinking TPC (Fig. 4).

The contribution of chl a from large algae $(>5 \mu \mathrm{m})$ to the total chl a sinking flux increased during early spring from initial values of $57.4,62.3$, and $66.5 \%$ at 1,15 , and $25 \mathrm{~m}$, respectively, on 27 March to median values of 87.7, 91.2 , and $89.0 \%$, respectively, after 13 April (Fig. 5a). The percent contribution of chl a from large algae $(>5 \mu \mathrm{m})$ did not change significantly with depth during the entire sampling period (Friedman's method, $\mathrm{p}>0.05$ ). The percent chl $a$ in total pigments showed some variability, but no significant seasonal trends (KruskalWallis, $\mathrm{p}>0.05$ ), with median values of $97.6,91.3$, and $76.0 \%$ at 1,15 , and $25 \mathrm{~m}$, respectively, throughout the entire sampling period (Fig. 5b). The percent contribution of chl a to total pigment sinking fluxes decreased significantly with depth throughout the study (Friedman's method, $\mathrm{p}<0.001$; Table 2).

Parallel seasonal patterns were observed in the POC:chl $a$, POC:BioSi, and PON:BioSi ratios of the sinking material throughout the study (Fig. 6a-c, Table 2). High ratios during the winter period (median values $2113 \mathrm{~g}: \mathrm{g}, 72.8$ and $14.0 \mathrm{~mol}: \mathrm{mol}$ at $1 \mathrm{~m}$, respectively) were followed by a decrease during the initial part of the early spring period (median values $110.9 \mathrm{~g}: \mathrm{g}, 11.0$ and $2.5 \mathrm{~mol}: \mathrm{mol}$ at $1 \mathrm{~m}$ during early spring, respectively). The POC:chl $a$ and POC:BioSi ratios remained rather stable after 13 April, while the PON:BioSi ratio showed a moderate decrease. All 3 ratios increased at $1 \mathrm{~m}$ from 14 June and onwards. A significant increase in the POC:chl a ratio was observed with depth throughout the study (Friedman's method, $\mathrm{p}<0.01$ ), while the POC:BioSi ratio showed no change and the PON:BioSi ratio showed a decrease with depth 


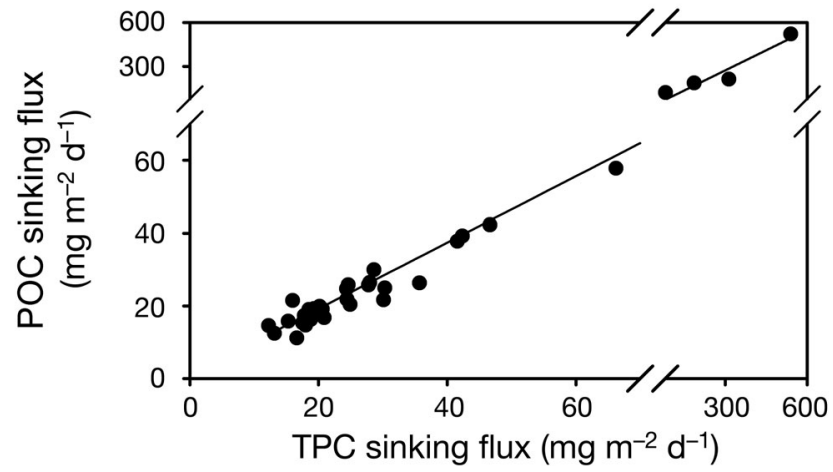

Fig. 4. Linear regression of particulate organic carbon (POC) sinking flux versus total particulate carbon (TPC) sinking flux at all depths, from particle interceptor trap deployments under the sea ice, from 5 April to 20 June 2004. Solid lines represent the simple linear regression (Model I): $y=0.91 x+1.0$, $\mathrm{r}^{2}=0.97, \mathrm{p}<0.001$

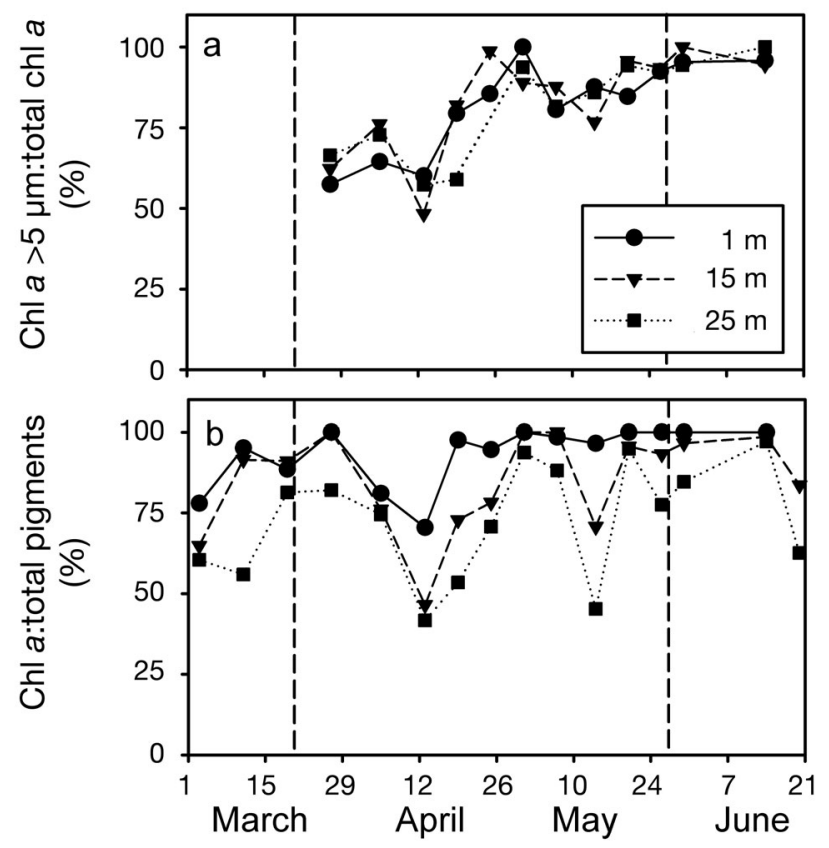

Fig. 5. Seasonal changes in (a) percent contribution of large phytoplankton $(>5 \mu \mathrm{m})$ to the total chl a sinking flux and (b) percent chl a in total pigments (chl $a+$ phaeopigments) in particle interceptor traps at 1, 15, and $25 \mathrm{~m}$ under the sea ice from 23 February to 20 June 2004. Data points represent particle interceptor trap recovery dates. Vertical dashed

lines represent reference periods as described in Table 1

(Friedman's method, p > 0.05 and $\mathrm{p}<0.05$, respectively; Table 2).

The POC:PON molar ratios of the sinking material remained rather stable prior to the melt period (median values of 4.5 and 4.2 at $1 \mathrm{~m}$ during the winter and early spring periods, respectively; Fig. 6d, Table 2). During the melt period, the POC:PON molar ratio at $25 \mathrm{~m}$ continuously increased to 12.3 on 20 June, while the ratios at 1 and $15 \mathrm{~m}$ peaked at ca. 11.2 on 30 May and

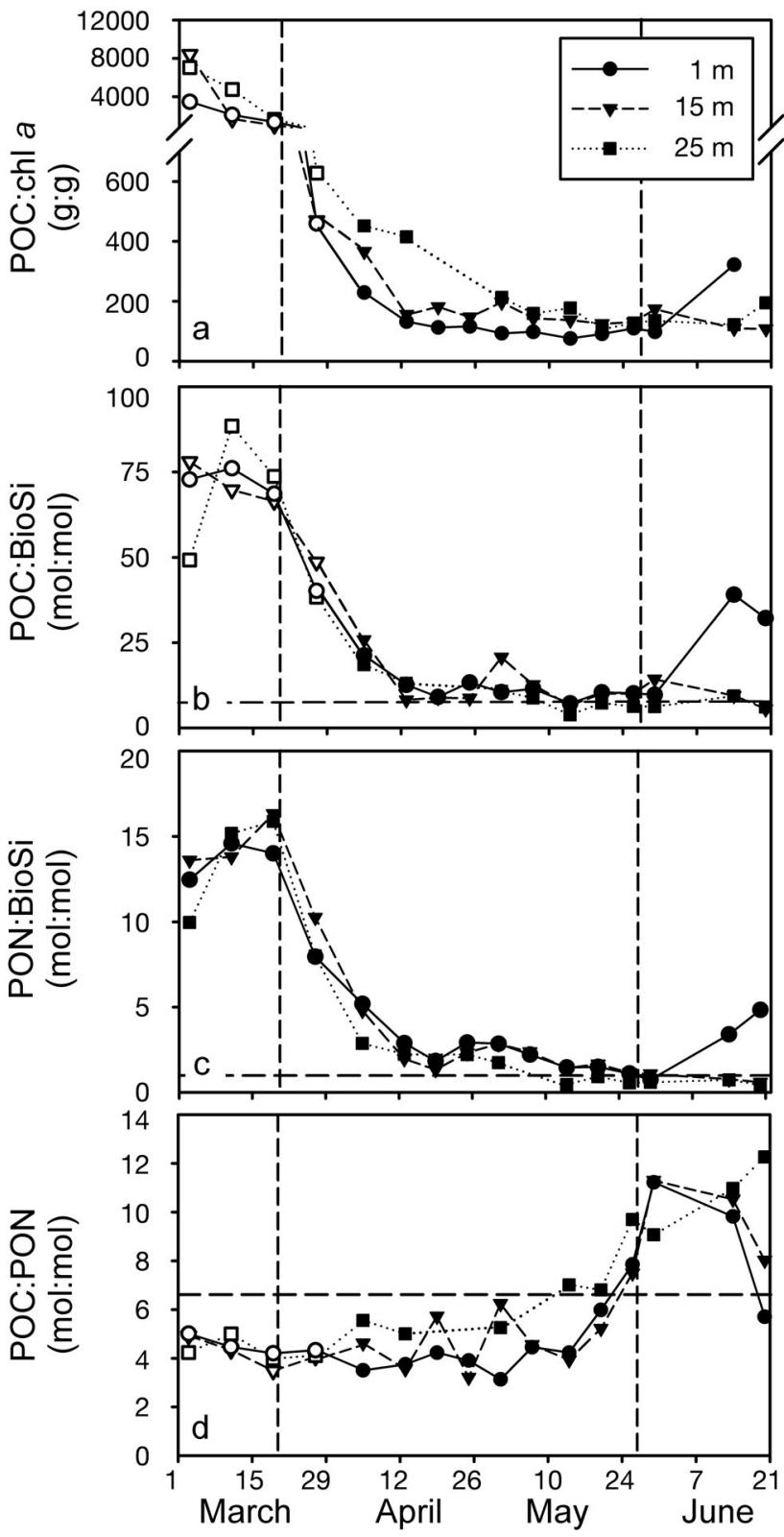

Fig. 6. Seasonal changes in the ratios of (a) particulate organic

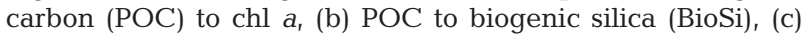
particulate organic nitrogen (PON) to $\mathrm{BioSi}$, and (d) POC to PON in particle interceptor traps at 1,15 , and $25 \mathrm{~m}$ under the sea ice from 23 February to 20 June 2004 . Data points represent particle interceptor trap recovery dates. The open data points in (a), (b), and (d) are POC values estimated from the linear relationship between $\mathrm{POC}$ and total particulate carbon (TPC). Vertical dashed lines represent reference periods as described in Table 1. In (b), (c), and (d), horizontal dashed lines represent the ratios of 7.1,1.1, and 6.6 of Redfield et al. (1963)

then decreased to between 6 and 8 on 20 June. The POC:PON ratio at $25 \mathrm{~m}$ was generally higher during early spring, although no significant change was observed with depth throughout the study (Friedman's method, p > 0.05; Table 2). 
Linear regressions between chl $a$ and BioSi sinking fluxes showed strong relationships at each sampling depth, with significantly increasing regression slopes with depth (analysis of covariance, $\mathrm{p}<0.01$; Fig. 7a). A significant linear relationship $\left(\mathrm{r}^{2}=0.51, \mathrm{p}<0.01\right)$ was observed between the sinking flux of chl $a$ at $1 \mathrm{~m}$ and the chl a biomass in the bottom ice (Fig. 7b). However, a stronger correlation $\left(\mathrm{r}^{2}=0.77, \mathrm{p}<0.001\right)$ was found when excluding the 2 maximum sea ice chl a biomass values observed on 7 May and 26 May (>16 mg chl a m${ }^{-2}$ ).

Daily sinking losses of chl $a$, POC, and PON from the sea ice and interfacial layer (top $1 \mathrm{~m}$ of the water column) showed parallel seasonal patterns throughout
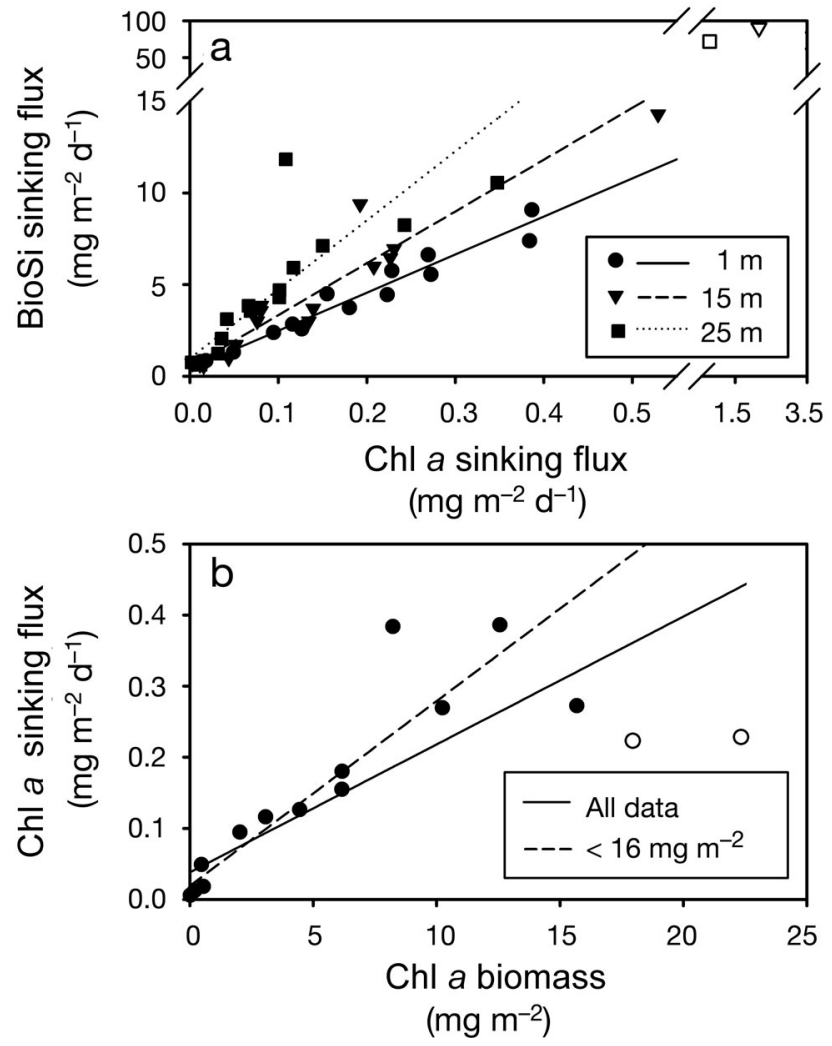

Fig. 7. Linear regressions (a) of biogenic silica (BioSi) sinking flux versus chl a sinking flux at 1, 15, and $25 \mathrm{~m}$, from particle interceptor trap deployments under the sea ice, from 23 February to 20 June 2004, and (b) of chl a sinking flux at $1 \mathrm{~m}$ versus chl a concentration in the sea ice bottom from 23 February to 14 June 2004 (sinking flux data not available on 20 June). In (a), lines represent reduced major axis (Model II) regressions using BioSi flux data $<15 \mathrm{mg} \mathrm{m}^{-2} \mathrm{~d}^{-1}$ (open symbols not included in regression lines). At $1 \mathrm{~m}: \mathrm{x}_{2}=41.54 \mathrm{x}_{1}+0.81, \mathrm{r}^{2}=0.96, \mathrm{p}<0.001 ; 15 \mathrm{~m}$ : $x_{2}=56.56 x_{1}+1.00, \mathrm{r}^{2}=0.91, \mathrm{p}<0.001 ;$ and $25 \mathrm{~m}: \mathrm{x}_{2}=62.16 \mathrm{x}_{1}+$ $2.16, r^{2}=0.93, p<0.001$. In (b), the solid line represents reduced major axis (Model II) regression for all data points: $x_{2}=0.018 x_{1}$ $+0.038, \mathrm{r}^{2}=0.51, \mathrm{p}<0.01$; and the dashed line represents reduced major axis (Model II) regression for ice algal biomasses $<16 \mathrm{mg}$ chl a m${ }^{-2}: \mathrm{x}_{2}=0.026 \mathrm{x}_{1}+0.019, \mathrm{r}^{2}=0.77, \mathrm{p}<0.001$. Open circles represent data points $>16 \mathrm{mg} \mathrm{chl} \mathrm{a} \mathrm{m}^{-2}$ the study (Fig. 8). The daily loss rates of chl $a$, POC, and PON decreased during winter and early spring, from maximum rates of $5.3,25.4$, and $35.0 \% \mathrm{~d}^{-1}$ to minimum rates of $1.0,2.0$, and $4.2 \% \mathrm{~d}^{-1}$, respectively. A subsequent increase was observed during the melt period, reaching daily loss rates of $4.2,14.3$, and $13.6 \% \mathrm{~d}^{-1}$ for chl $a$, POC, and PON, respectively.

\section{DISCUSSION}

\section{Seasonal variations in under-ice sinking fluxes}

This study started during winter (23 February), at a time when bottom ice algal biomass was still very low (Fig. 2c). Little algal material was collected by the underice particle interceptor traps before early spring, as shown by the low chl a $\left(<0.02 \mathrm{mg} \mathrm{chl} a \mathrm{~m}^{-2} \mathrm{~d}^{-1}\right)$ and BioSi sinking fluxes $\left(<1 \mathrm{mg} \mathrm{m}^{-2} \mathrm{~d}^{-1}\right)$. To our knowledge, only one other study has estimated the sinking export of organic material near Franklin Bay during winter, using long-term sediment traps deployed at $145 \mathrm{~m}$ (O'Brien et al. 2006, their Stn SS-1; see our Fig. 1). These authors reported low chl a $\left(<0.003 \mathrm{mg}\right.$ chl a m$\left.{ }^{-2} \mathrm{~d}^{-1}\right)$ and BioSi $\left(<10 \mathrm{mg}\right.$ BioSi $\left.\mathrm{m}^{-2} \mathrm{~d}^{-1}\right)$ sinking fluxes from December to March.

The fairly constant POC fluxes (median values of 21.0 and $24.6 \mathrm{mg} \mathrm{m}^{-2} \mathrm{~d}^{-1}$ at $1 \mathrm{~m}_{\text {; Fig. }} 3 \mathrm{~d}$, Table 2) until the onset of spring melt indicate negligible seasonal changes in the sinking export of POC. Although O'Brien et al. (2006) observed strong seasonality in POC sinking fluxes on the Mackenzie Shelf, they reported POC sinking fluxes of $<10 \mathrm{mg} \mathrm{C} \mathrm{m}^{-2} \mathrm{~d}^{-1}$ at $145 \mathrm{~m}$ under the sea ice near Franklin Bay (their Stn SS-1; see our Fig. 1), during April 1987 and from November 1987 to March 1988. Forest et al. 2007

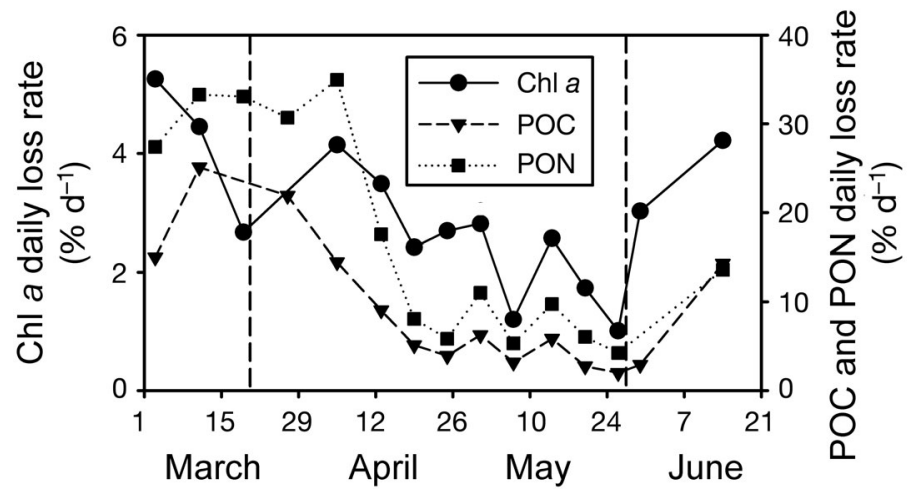

Fig. 8. Seasonal changes in the daily sinking loss rate of chl a and particulate organic carbon and nitrogen (POC and PON) at $1 \mathrm{~m}$ under the sea ice from 23 February to 20 June 2004. Data points represent particle interceptor trap recovery dates. Vertical dashed lines represent reference periods as described in Table 1 
reported comparable POC sinking fluxes at $200 \mathrm{~m}$, from October 2003 to May 2004, on the Mackenzie Shelf slope (<15 $\mathrm{mg} \mathrm{C} \mathrm{m}^{-2} \mathrm{~d}^{-1}$ at their Stn CA-04 and CA-07; see our Fig. 1), with episodic events of POC advection from the shelf onto the shelf-slope during winter and spring. Despite differences in sampling depths between our study and these studies, these observations show that under-ice sinking export of POC does take place on the Mackenzie Shelf during the winter.

Several studies looking at temporal changes in under-ice sinking fluxes of organic material have shown increasing sinking fluxes in response to the release of material from the sea ice during spring melt (Carey 1987, Tremblay et al. 1989, Michel et al. 1996, Fortier et al. 2002). Melnikov (1998) suggested that ice algae in the western Weddell Sea are released from the ice during winter through brine drainage during ice growth. Furthermore, Carey (1987) suggested that the carbon sinking flux measured near the bottom in the vicinity of Narwhal Island (southwestern Beaufort Sea) from mid-April to end of May primarily originated from the productive ice communities prior to ice melt. During the present study, ice thickness continuously increased until the onset of spring ice melt, indicating that any release of organic material from the ice during that period would be linked to brine drainage rather than melt processes. An early coupling between ice communities and the underlying water column, prior to spring ice melt, could be of seasonal importance for pelagic herbivores, as suggested by Melnikov (1998), as well as for the benthic community as suggested by Renaud et al. (2007).

The increasing pelagic grazing activity of copepods observed by Seuthe et al. (2007) during the winterspring transition in Franklin Bay, although linked to pelagic primary production, may have been supplemented with sinking ice algal material. Indeed, microscopic observations of fecal pellets in sediment traps showed that they contained frustules of pennate diatoms (L. Seuthe unpubl. data), the most abundant algal group in the bottom surface of the ice in AprilMay (M. Różańska pers. comm.). During our study, bottom ice algal concentrations were, on average, more than 2 orders of magnitude higher than phytoplankton concentrations at $1 \mathrm{~m}$, indicating that any phytoplankton contribution to sinking algae would be minimal.

Assuming that the POC sinking flux measured during the winter period in the present study would have been the same throughout the preceding winter months, we can estimate that ca. $3.5 \mathrm{~g} \mathrm{C} \mathrm{m}^{-2}$ would have been exported through sinking from November to the end of March. This POC sinking flux estimate for the winter period is almost 1 order of magnitude higher than that reported by O'Brien et al. (2006) near Franklin Bay for November to March $\left(<0.5 \mathrm{~g} \mathrm{C} \mathrm{m}^{-2}\right.$ at $145 \mathrm{~m}$ at their Stn SS-1), and compares with their annual POC sinking flux estimate (ca. $4 \mathrm{~g} \mathrm{C} \mathrm{m}^{-2}$ ). The discrepancy between our results and those obtained by O'Brien et al. (2006) is likely explained by transformation and loss processes affecting the organic material during its descent to deep waters. This aspect will be discussed in more detail in the next section. In addition, the different methods and interannual and spatial differences between the 2 studies probably also contributed to the observed discrepancy.

The fairly constant POC sinking fluxes prior to spring melt compared to the observed changes in chl $a$ and BioSi fluxes suggests a non-algal origin of the sinking POC during winter. This is supported by the high POC:chl a ratios and the POC:BioSi and PON:BioSi molar ratios, which were considerably higher than Redfield ratios (7.1 and 1.1, respectively; Redfield et al. 1963), during the winter period (Fig. 6a-c). The POC sinking fluxes during the winter period did not appear to be related to the sinking of senescent algae or herbivorous fecal material, as evidenced by negligible sinking fluxes of phaeopigments $\left(\leq 0.002 \mathrm{mg} \mathrm{m}^{-2} \mathrm{~d}^{-1}\right.$; Table 2) and low POC:PON molar ratios compared to those reported for copepod fecal pellets (33.2; Daly et al. 1999). Qualitative microscopic analysis of the sinking material collected during winter revealed large amounts of gelatinous material to which detritus were attached, possibly transparent exopolymeric particles (TEP). TEP produced by diatoms have high C:N molar ratios (26; Engel \& Passow 2001). This, in combination with the low abundance of sea ice diatoms during winter, does not support that the TEP in the sinking material would have originated from diatoms. Bhaskar et al. (2005) reported low C:N molar ratios (2.4) in bacterial exopolymeric substances (EPS). The transparent Coomassie Stained Particles (CSP), first described by Long \& Azam (1996), can be produced by marine bacterioplankton and likely have a high nitrogen content due to their protein composition (Radić et al. 2006). Bacteria also have low C:N ratios (3.2; Lee \& Fuhrman 1987). We thus surmise that bacteria-mediated sinking fluxes contributed significantly to the export of organic material during winter.

The initial increase in under-ice chl $a$ and BioSi sinking fluxes coincided with the increasing bottom ice chl a biomass, suggesting a coupling between sinking fluxes under the sea ice and ice algal biomass. Indeed, a significant relationship between sinking fluxes and ice algal biomass was observed during the present study (Fig. 7b). This relationship was stronger at lower ice algal biomass concentrations. The higher and more variable data points in the regression plot represent measurements obtained toward the onset of spring 
melt, indicating a stronger relationship between sinking fluxes and ice algal biomass during winter and early spring.

The POC:chl $a$ ratios during early spring (median

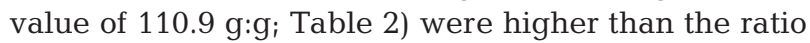
typically considered for healthy algal cells $\left(40 \mathrm{~g}: \mathrm{g}_{\text {; }}\right.$ Lorenzen 1968), but were within the range reported for ice algae (ca. 15 to $180 \mathrm{~g}: g$; Gosselin et al. 1990). Using the POC:chl a ratio for the bottom ice algae during our study (44 g:g; A. Riedel pers. comm.), the estimated sinking export of POC explained by algal cells would, on average, be $7.5 \mathrm{mg} \mathrm{C} \mathrm{m} \mathrm{m}^{-2} \mathrm{~d}^{-1}$ or $37.8 \%$ of the observed POC sinking flux during early spring. This indicates that a significant part of the POC sinking flux was explained by algal cells during early spring. Diatoms appeared to become a seasonally increasing fraction of the algal sinking flux, as supported by the increase in the contribution of chl $a>5 \mu \mathrm{m}$ to the total chl a sinking flux, the increasing BioSi sinking flux, and the decreasing POC:BioSi and PON:BioSi ratios during early spring. Indeed, increasing sinking fluxes of algal cells, dominated by the pennate diatoms Nitzschia frigida and Navicula spp., were observed from March to May (from 3.2 to $118.0 \times 10^{6}$ cells m$^{-2} \mathrm{~d}^{-1}$ at $1 \mathrm{~m} ; \mathrm{A}$. Tatarak pers. comm.). These 2 species were also dominant in the ice assemblage (M. Różańska pers. comm.).

Analyses of vertical sections of ice cores showed that on average, $95 \%$ of the total chl a biomass in complete ice cores was found in the bottom $4 \mathrm{~cm}$ (A. Riedel pers. comm.). Therefore, the initial melting of the bottom section of the sea ice would presumably result in a higher release of organic material compared to later melt farther up in the vertical ice profile. During the spring melt period, sinking fluxes of organic material increased significantly in response to the onset of spring ice melt after 26 May. This initial and rapid increase in sinking fluxes was observed in all measured variables, suggesting that all ice-bound material in the bottom ice was rapidly released. The coincident increase in the POC:chl $a, \mathrm{POC}: \mathrm{BioSi}$, and PON:BioSi ratios at $1 \mathrm{~m}$ suggest that not only ice algal cells, but other organic material previously retained within the sea ice was released during the melt period. The increase in sinking export of chl a observed during the

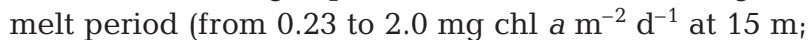
data from $1 \mathrm{~m}$ not available on 20 June) is comparable to increases reported during spring ice melt in Resolute Passage (from $<0.1$ to $2.3 \mathrm{mg} \mathrm{chl} \mathrm{a} \mathrm{m} \mathrm{m}^{-2} \mathrm{~d}^{-1}$ at $15 \mathrm{~m}$ in May and June; Michel et al. 1996) or southeastern

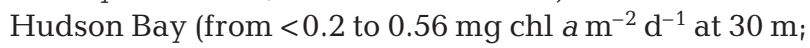
Tremblay et al. 1989). Moreover, the sinking export of ice algal material at $1 \mathrm{~m}$ integrated over the spring

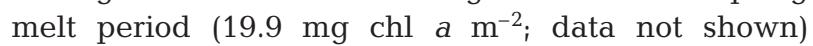
exceeded the sinking export at $1 \mathrm{~m}$ integrated over the winter and early spring periods $\left(11.4 \mathrm{mg} \mathrm{chl} a \mathrm{~m}^{-2}\right.$; data not shown). Hence, the bulk of the sea ice biomass was released during the spring melt, although the earlier sinking export of ice algal material may still be of seasonal importance to pelagic (Melnikov 1998) and benthic (Renaud et al. 2007) communities.

\section{Depth-related changes in the composition of the sinking material}

The rationale for deploying multiple particle interceptor traps at successive depths under the sea ice was to assess the initial changes in the amount and composition of the sinking flux of particulate material. Throughout the study, almost half of the chl a was lost from the sinking particulate material within the upper $25 \mathrm{~m}$, as seen in the decreasing chl a sinking fluxes with depth (Fig. 3a, Table 2). Assuming that there was no loss of material due to advective processes, this loss of chl a during sinking would have been caused by grazing and/or degradation. The constant sinking fluxes of BioSi, TPC, and POC with depth support that the loss of chl a was not due to advective processes, since these variables would presumably have been equally affected by advection. Several studies have shown that the heterotrophic food web may be capable of assimilating a considerable proportion of the ice algal biomass after its release from the ice (Carey 1987, Tremblay et al. 1989, Michel et al. 1996, Fortier et al. 2002). These studies all show variability in the amount and composition of the sinking organic material in Arctic coastal areas, due to differences in the pelagic heterotrophic food web structure (e.g. Fortier et al. 2002). During our study, grazing and subsequent transformation of chl a to phaeopigments (Fig. 5b, Table 2) appeared to take place within the top $25 \mathrm{~m}$. Increasing copepod grazing rates were observed in April and May (Seuthe et al. 2007), adding support to a possible grazing loss of the sinking algal material.

The increasing POC:PON ratio of the sinking material with depth (Fig. 6d, Table 2), although not statistically significant, could also indicate herbivorous grazing. However, the POC:PON molar ratios were well below the Redfield ratio at all depths until late in the season (26 May; Fig. 6d) and therefore do not provide a clear indication of grazing (e.g. Daly et al. 1999). In addition, copepods are for the most part limited to ingesting large cells (e.g. Frost 1972), such that grazing on the sinking algal material would likely result in a reduction of the large chl a size fraction $(>5 \mu \mathrm{m})$ with depth. During the present study, no change in the relative contribution of chl a size fractions with depth was observed, thus suggesting a minor influence of large grazers on the sinking material. An alternate explana- 
tion for the increasing POC:PON ratio of the sinking material with depth would be preferential remineralization of PON compared to POC. Active microbial communities associated with the sinking material (see previous section) would certainly favor such a pathway.

We observed strong relationships between BioSi and chl a (Fig. 7a) and BioSi and total pigments (data not shown) at all depths, with regression slopes increasing significantly with depth. These trends were expected, since BioSi is subject to dissolution rather than biological degradation, although bacterial activity increases the rate of BioSi dissolution (Bidle \& Azam 1999). Diatom frustules are often found undigested in herbivorous copepod fecal pellets after passing through the digestive tract (Turner 2002), as observed during the present study (L. Seuthe unpubl. data). The constant BioSi sinking fluxes with depth therefore reflect that diatom frustules were preserved, either as intact diatom cells or empty frustules, in the material sinking in the upper water column.

The spring ice melt (after 26 May) did not result only in increased sinking fluxes of particulate material, but also in changes to the composition of the sinking material. The higher POC:chl a, POC:BioSi, and PON:BioSi ratios at $1 \mathrm{~m}$ compared to other depths (Fig. 6a-c) resulted from a more moderate increase in the chl $a$ and BioSi sinking fluxes compared to those of POC and PON at $1 \mathrm{~m}$. The freshening of the surface layer during the melt period (Fig. 2b) could explain the differences in the composition of the material collected at $1 \mathrm{~m}$ compared to other depths. Selective retention of particles with different densities, with low-density particles being retained above a pycnocline, could come into play. Under such a scenario, i.e. with the pycnocline acting as a barrier to the sedimentation of certain particles, vertical changes in sinking fluxes would not directly reflect the transformation of the sinking material with depth, but rather differential sinking of particles. A freshening of the surface layer only occurred during the melt period (Fig. 2b) and the thermocline remained for the most part below the deployment depths (Forest et al. 2007), which suggests that vertical changes in sinking fluxes observed during winter and early spring were linked to depth-related transformation of the sinking material.

\section{Loss of biomass through sinking export}

The overall decreasing trend in the daily loss of chl a until the spring ice melt (Fig. 8) indicates that the seasonal increase in sea ice chl a biomass was not matched equally by the increasing chl a sinking export. The parallel seasonal patterns in the sinking loss of chl $a$, POC, and PON suggest that these variables were closely linked and likely reflected the sinking export of algal material. Michel et al. (2002) observed comparable daily sinking loss rates of chl a (up to $10 \% \mathrm{~d}^{-1}$ ) and POC ( 5 to $22 \% \mathrm{~d}^{-1}$ ) at $1 \mathrm{~m}$ under first-year sea ice in northern Baffin Bay during April and May. During the present study, between 1.0 and $5.3 \%$ of the chl a biomass, 2.0 and $25.4 \%$ of the POC biomass, and 4.2 and $35.0 \%$ of the PON biomass was exported daily from the sea ice and interfacial layer through sinking. In the course of this 4 mo study, an estimated $31.3 \mathrm{mg}$ chl $a \mathrm{~m}^{-2}, 7.2 \mathrm{~g} \mathrm{C} \mathrm{m}^{-2}$ (POC), and $1.2 \mathrm{~g} \mathrm{~N} \mathrm{~m}^{-2}$ (PON) were exported through sinking at $1 \mathrm{~m}$ under the firstyear sea ice in Franklin Bay. In comparison, the underice sinking export of POC during a $54 \mathrm{~d}$ spring study in Resolute Passage was 11 to $12 \mathrm{~g} \mathrm{C} \mathrm{m}^{-2}$ at $15 \mathrm{~m}$, of which most ( 8 to $11 \mathrm{~g} \mathrm{C} \mathrm{m}^{-2}$ ) remained suspended during the period of study (Michel et al. 1996). These POC sinking export values are considerably higher than the estimate reported by O'Brien et al. (2006) from April to May (ca. $0.5 \mathrm{~g} \mathrm{C} \mathrm{m}^{-2}$ at $145 \mathrm{~m}$; their Stn SS-1), which may be related to a high degradation of the organic material during sinking to depth.

\section{CONCLUSIONS}

This study showed a tight coupling between the sinking export of algal material and the biomass of ice algae, especially during winter and at the beginning of the early spring period. The observed coupling between ice biomass and sinking export suggests that ice algae can provide a potential food source for the pelagic and benthic communities well before the onset of spring melt. The decreasing sinking fluxes of chl a with depth (46\% from 1 to $25 \mathrm{~m}$ ), showed a considerable loss of pigmented biomass from the sinking particulate organic material after its release from the ice. Diatoms comprised a seasonally increasing fraction of the sinking algal material during early spring, as indicated by the increasing fraction of large chl a (>5 $\mu \mathrm{m})$ and BioSi sinking fluxes. In contrast with the seasonally increasing sinking fluxes of chl $a$ and BioSi, the POC sinking fluxes remained rather stable until the onset of spring melt. A large part of the sinking POC appeared to be non-algae related, as suggested by the high POC:chl a ratios. The onset of spring melt resulted in a considerable increase in sinking fluxes of pigmented and non-pigmented material, indicating a non-selective release of particulate organic material from the sea ice. However, our results also suggest retention of some of the released particulate material within the low salinity surface layer (between 1 and $15 \mathrm{~m}$ ) formed at the time of ice melt. Our daily loss rate estimates showed that highest sinking losses of biomass occurred during late winter. 
Acknowledgements. This study was supported by grants from the Natural Sciences and Engineering Research Council (NSERC) of Canada (Research Network grant to C.M. and M.G.) and from the Department of Fisheries and Oceans Canada (Strategic Research Fund to C.M.). Partial operating funds for the 'CCGS Amundsen' were provided by the International Joint Ventures Fund of the Canada Foundation for Innovation and the Fonds québécois de la recherche sur la nature et les technologies (FQRNT). T.J.P. received postgraduate scholarships from the Institut des sciences de la mer de Rimouski (ISMER) and Université du Québec à Rimouski (Exemptions des frais majorés pour étudiants étrangers). The authors are particularly grateful to B. LeBlanc for his tremendous efforts in the field and laboratory. We thank J. Wiktor and A. Tatarek for providing information on algal species composition in the trap samples and M. Różańska for information on the ice algal community; and D. Bérubé, S. Brugel, J. Ferland, K. Lacoste, M. Lizotte, W. Moskal, M. Poulin, A. Riedel, M. Simard, M. Zajaczkowski and our other collaborators for their assistance. We also thank 3 anonymous reviewers for insightful comments on the manuscript. Special thanks to the officers and crew onboard the 'CCGS Amundsen' and the Canadian Arctic Shelf Exchange Study (CASES) for the invaluable support throughout this study. This is a contribution to the research programs of CASES, the Freshwater Institute (Fisheries and Oceans Canada), ISMER, and Québec-Océan. We dedicate this paper to the memory of Prof. Grant Ingram, a friend, mentor, and colleague of CASES and many other Arctic projects.

\section{LITERATURE CITED}

Bhaskar PV, Grossart HP, Bhosle NB, Simon M (2005) Production of macroaggregates from dissolved exopolymeric substances (EPS) of bacterial and diatom origin. FEMS Microbiol Ecol 53:255-264

Bidle KD, Azam F (1999) Accelerated dissolution of diatom silica by marine bacterial assemblages. Nature 397:508-512

Carey AG Jr (1987) Particle flux beneath fast ice in the shallow southwestern Beaufort Sea, Arctic Ocean. Mar Ecol Prog Ser 40:247-257

Carmack EC, Macdonald RW (2002) Oceanography of the Canadian Shelf of the Beaufort Sea: a setting for marine life. Arctic 55:29-45

Carmack EC, Macdonald RW, Jasper S (2004) Phytoplankton productivity on the Canadian Shelf of the Beaufort Sea. Mar Ecol Prog Ser 277:37-50

Conley DJ (1998) An interlaboratory comparison for the measurement of biogenic silica in sediments. Mar Chem 63: 39-48

Daly KL, Wallace DWR, Smith WO, Skoog A and others (1999) Non-Redfield carbon and nitrogen cycling in the Arctic: effects of ecosystem structure and dynamics. J Geophys Res 104:3185-3199

Engel A, Passow U (2001) Carbon and nitrogen content of transparent exopolymer particles (TEP) in relation to their Alcian Blue adsorption. Mar Ecol Prog Ser 219:1-10

Forest A, Sampei M, Hattori H, Makabe R and others (2007) Particulate organic carbon fluxes on the slope of the Mackenzie Shelf (Beaufort Sea): physical and biological forcing of shelf-basin exchanges. J Mar Syst 68:39-54

Fortier M, Fortier L, Michel C, Legendre L (2002) Climatic and biological forcing of the vertical flux of biogenic particles under seasonal Arctic sea ice. Mar Ecol Prog Ser 225:1-16

Frost BW (1972) Effects of size and concentrations of food particles on the feeding behavior of the marine planktonic copepod Calanus pacificus. Limnol Oceanogr 17:805-815

Gardner WD (2000) Sediment trap sampling in surface waters: issues and recommendations. In: Hanson RB, Ducklow HW, Field JG (eds) The changing ocean carbon cycle: a midterm synthesis of the Joint Global Ocean Flux Study. Cambridge University Press, Cambridge, p 240-281

Gosselin M, Legendre L, Therriault JC, Demers S (1990) Light and nutrient limitation of sea-ice microalgae (Hudson Bay, Canadian Arctic). J Phycol 26:220-232

Gosselin M, Levasseur M, Wheeler PA, Horner RA, Booth BC (1997) New measurements of phytoplankton and ice algae production in the Arctic Ocean. Deep-Sea Res II 44: 1623-1644

Horner R, Schrader GC (1982) Relative contributions of ice algae, phytoplankton and benthic microalgae to primary production in nearshore regions of the Beaufort Sea. Arctic 35:485-503

Jakobsson M (2002) Hypsometry and volume of the Arctic Ocean and its constituent seas. Geochem Geophys Geosyst 3:1028, doi:10.1029/2001GC000302

Knap A, Michaels A, Close A, Ducklow H, Dickson A (1996) Protocols for the Joint Global Ocean Flux Study (JGOFS) core measurements. JGOFS Report Nr. 19. Reprint of the IOC Manuals and Guides No. 29, UNESCO, Bergen

Lavoie D, Denman K, Michel C (2005) Modelling ice algal growth and decline in a seasonally ice-covered region of the Arctic (Resolute Passage, Canadian Archipelago). J Geophys Res 110:C11009, doi:10.1029/2005JC002922

Lee S, Fuhrman JA (1987) Relationships between biovolume and biomass of naturally derived marine bacterioplankton. Appl Environ Microbiol 53:1298-1303

Long RA, Azam F (1996) Abundant protein-containing particles in the sea. Aquat Microb Ecol 10:213-221

Lorenzen CJ (1968) Carbon/chlorophyll relationships in an upwelling area. Limnol Oceanogr 13:202-204

Macdonald RW, Solomon SM, Cranston RE, Welch HE, Yunker MB, Gobeil C (1998) A sediment and organic carbon budget for the Canadian Beaufort Sea. Mar Geol 144: 255-273

McMahon KW, Ambrose WG Jr, Johnson BJ, Sun MY, Lopez GR, Clough LM, Carroll ML (2006) Benthic community response to ice algae and phytoplankton in Ny Ålesund, Svalbard. Mar Ecol Prog Ser 310:1-14

Melnikov IA (1998) Winter production of sea ice algae in the western Weddell Sea. J Mar Syst 17:195-205

Michel C, Legendre L, Ingram RG, Gosselin M, Levasseur M (1996) Carbon budget of sea-ice algae in spring: evidence of a significant transfer to zooplankton grazers. J Geophys Res 101:18345-18360

Michel C, Nielsen TG, Nozais C, Gosselin M (2002) Significance of sedimentation and grazing by ice micro- and meiofauna for carbon cycling in annual sea ice (northern Baffin Bay). Aquat Microb Ecol 30:57-68

Møller EF, Thor P, Nielsen TG (2003) Production of DOC by Calanus finmarchicus, C. glacialis and C. hyperboreus through sloppy feeding and leakage from faecal pellets. Mar Ecol Prog Ser 262:185-191

Nozais C, Gosselin M, Michel C, Tita G (2001) Abundance, biomass, composition and grazing impact of the sea-ice meiofauna in the North Water, northern Baffin Bay. Mar Ecol Prog Ser 217:235-250

O'Brien MC, Macdonald RW, Melling H, Iseki K (2006) Particle fluxes and geochemistry on the Canadian Beaufort Shelf: implications for sediment transport and deposition. Cont Shelf Res 26:41-81

Parsons TR, Maita Y, Lalli CM (1984) A manual of chemical and biological methods for seawater analysis. Pergamon Press, Toronto 
Radić T, Ivanćić I, Fuks D, Radić J (2006) Marine bacterioplankton production of polysaccharide and proteinaceous particles under different nutrient regimes. FEMS Microbiol Ecol 58:333-342

Ragueneau O, Tréguer P (1994) Determination of biogenic silica in coastal waters: applicability and limits of the alkaline digestion method. Mar Chem 45:43-51

Redfield AC, Ketchum BH, Richards FA (1963) The influence of organisms on the composition of sea water. In: Hill MN (ed) The sea. Wiley, New York, p 26-77

Renaud PE, Riedel A, Michel C, Morata N, Gosselin M, JuulPedersen T, Chiuchiolo A (2007) Seasonal variation in benthic community oxygen demand: a response to an ice algal bloom in the Beaufort Sea, Canadian Arctic? J Mar Syst $67: 1-12$

Riedel A, Michel C, Gosselin M (2006) Seasonal study of seaice exopolymeric substances on the Mackenzie Shelf: implications for the transport of sea-ice bacteria and algae. Aquat Microb Ecol 45:195-206

Seuthe L, Danis G, Riser CW, Wassmann P, Fortier L (2007) Winter-spring feeding and metabolism of Arctic copepods: insights from faecal pellet production and respiration mea-

Editorial responsibility: Otto Kinne (Editor-in-Chief), Oldendorf/Luhe, Germany surements in the southeastern Beaufort Sea. Polar Biol 30: $427-436$

Smith REH, Harrison WG, Harris LR, Herman AW (1990) Vertical fine structure of particulate matter and nutrients in sea ice of the high Arctic. Can J Fish Aquat Sci 47: 1348-1355

Sokal RR, Rohlf FJ (1981) Biometry: the principles and practice of statistics in biological research, 2nd edn. WH Freeman, San Francisco, CA

Tremblay C, Runge JA, Legendre L (1989) Grazing and sedimentation of ice algae during and immediately after a bloom at the ice-water interface. Mar Ecol Prog Ser 56: 291-300

Turner JT (2002) Zooplankton fecal pellets, marine snow and sinking phytoplankton blooms. Aquat Microb Ecol 27: 57-102

Wassmann P (1998) Retention versus export food chains: processes controlling sinking loss from marine pelagic systems. Hydrobiologia 363:29-57

Werner I (2000) Faecal pellet production by Arctic under-ice amphipods - transfer of organic matter through the ice/ water interface. Hydrobiologia 426:89-96

Submitted: April 11, 2007; Accepted: July 18, 2007

Proofs received from author(s): December 6, 2007 